
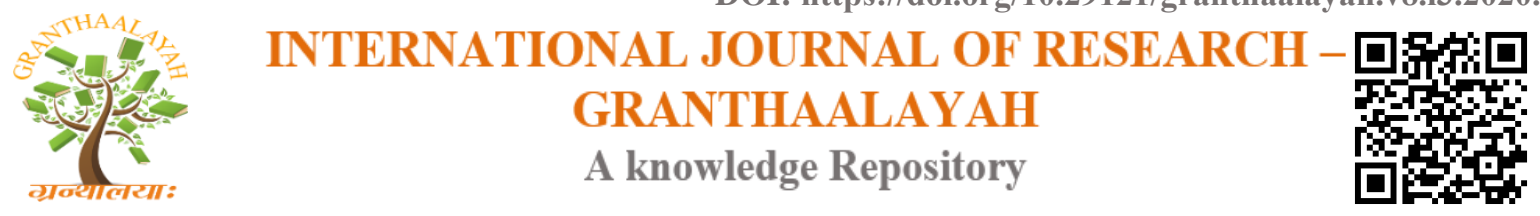

Science

\title{
REVIEW OF RASAYANA TANTRA- A UNIQUE APPROACH IN HEALING
}

\author{
Dr. Shriram Shivajirao Ragad ${ }^{1}$, Dr. Sunil Tulshiramji Mehetre ${ }^{2}$ \\ ${ }^{1}$ M. D. Ayurved (Panchakarma) Assistant Professor, Panchakarma Department, S. C. Mutha \\ Aryangla Vaidyak Mahavidyalay, Satara-415002, India \\ ${ }^{2}$ Dr. Sunil Tulshiramji Mehetre, M. D. Ayu Sharirkriya, Associate Professor, Department of \\ Kriyasharir, Seth Chandanmal Mutha Aryangla Vaidyak Mahavidyalaya, Satara-415002, India
}

\begin{abstract}
There are eight branches of Ayurveda, Rasayana chikitsa is one of them.it is also known as jarachikitsa (anti-aging treatment) In Ayurveda there is not only reduce the symptoms of disease but also remove it from route. 'Prvention is better than cure' Ayurveda also prevent this life style disorder by nidan parivarjana, panchkarma,Rasayana chikitsa, following pathya-apthya. The concept of Rasayna-chikitsa as a branch has its own importance not only in the old age but need to be commenced in the early stage.

The present article described whole about the Rasayana-chikitsa, epidemiology, types, methodology and its effect on the body.
\end{abstract}

Keywords: Rasayana; Ayurveda; Effects; Review.

Cite This Article: Dr. Shriram Shivajirao Ragad, and Dr. Sunil Tulshiramji Mehetre. (2020). "REVIEW OF RASAYANA TANTRA- A UNIQUE APPROACH IN HEALING." International Journal of Research - Granthaalayah, 8(3), 357-365.

\section{Introduction}

The ancient knowledge of Ayurveda will help to prevent and management of life style disorder in present era very well. The classification to consider treatment for ageing (Jara chikitsa) ${ }^{(1)}$ as synonymous with Rasayana-chikitsa (Rasayana treatment) as one of the eight branches of Ayurveda is not only to specialize certain methods in any particular knowledge domain of the Ayurvedic system but as a process by which the body tissues attain its best capacity to perform their systemic activities (. As one the eight branches of Ayurveda, Rasayana-chikitsa is applicable in all branches of Ayurveda irrespective of any particular domain of knowledge and it has great relevance as a procedure to attain and maintain good health. 


\section{Etymology of Rasayana}

Analyzing the etymology of the word "Rasayana" gives good insight to the purpose, for which the Rasayana tantra has been developed throughout the history of Ayurveda. The word "Rasayana" consists of two words, i.e., "rasa" and "ayana".

- $\boldsymbol{R} \boldsymbol{a s a}$ is derived from \& ras dhatu, the verb is rasayati, rasyate, which means to taste, to relish, to desire, etc. The word rasa denotes the sap, the finest part of anything, essence, marrow, elixir, melted butter, milk, poison, nectar namata), soup, the prime fluid of the body (visishta rasa dhatu), mercury (parada), semen, gold (suvarna), six tastes (shad rasa), the sentiment, love, desire, etc. ${ }^{(2)}$

- Ayana is derived from $\mathbf{i}$ or ay dhatu, the verb is ayati, ayate, which means to go, to walk, to flow, to advance, etc. The word ayana denotes the going, walking, path, course, circulation, advancing, etc ${ }^{(3)}$.

- Rasayana, the combined word means an alchemist, a channel for the(body) fluids, a medicine supposed to prevent old age and prolong life, an elixir, buttermilk, poison, employment of mercury nparada prayoga), a drug used in vermifuge (Embelia ribes), long pepper, Terminalia chebula (Citrina),

\section{Types of Rasayana therapy $(4,5,6)$}

There are various types of Rasayana therapies, classified on the basis of administration, therapeutic model, etc.

Table 1: Types of the Rasayana therapy

\begin{tabular}{|c|c|c|}
\hline \multicolumn{3}{|c|}{ Dvividha bheda } \\
\hline $\begin{array}{c}\text { 1.kutipraveshika } \\
\text { 2. vatatapika }\end{array}$ & $\begin{array}{l}\text { 1.dravyabhuta, i.e., ghrta etc. } \\
\text { 2.Adravyabhuta, i.e., achara } \\
\text { rasayana }\end{array}$ & $\begin{array}{l}\text { 1.samshodhana } \\
\text { 2.samshamana }\end{array}$ \\
\hline \multicolumn{3}{|c|}{ Trividha bheda } \\
\hline 1.kamya & \multirow{3}{*}{$\begin{array}{l}\text { 1.jangama, i.e.dugdha } \\
\text { 2.Audbhida, i.e.guduchi } \\
\text { 3.parthiva, i.e. shilajatu }\end{array}$} & \\
\hline 2.naimittika & & \\
\hline 3.ajashrika & & \\
\hline \multicolumn{3}{|c|}{ 1.Abhayamalaki rasayana pada } \\
\hline \multicolumn{3}{|c|}{ 2.Pranakamiya rasayana pada } \\
\hline \multicolumn{3}{|c|}{ 3.Karapracitiya rasayana pada } \\
\hline \multicolumn{3}{|c|}{ 4.Ayurvedasamutthaniya rasayana pada } \\
\hline
\end{tabular}




\section{Methodology of Rasayana Therapy}

The outcome of Rasayana therapy depends upon the degree of adapting and observing these procedures. That include purva karma, pradhana karma and pashchta karma ${ }^{(7)}$. Purva karma includes the shamana and shodhana cikitsa, to have a purified body (shuddha sharira), to which a suitable Rasayana ausadha is administered. The administration of a suitable Rasayana ausadha becomes the pradhana karma in the context of Rasayana therapy. During the Rasayana treatment and after the completion of the treatment, one has to adhere to the Achara Rasayana, which consists of using Ahara and vihara and ausadha, the instructions to be followed during this period is known as pashchata karma. Pashchhat karma consists of parihara kala, which is twice the duration of pradhana karma. After the parihara kala, the individual is allowed to use normal diet ${ }^{(8)}$.

Table 2: The sequence of the Rasayana therapy

\begin{tabular}{|l|l|l|}
\hline Purva karma & Pradhana karma & Pashchata karma \\
\hline building a kuti & $\begin{array}{l}\text { administration of Rasayana } \\
\text { yoga }\end{array}$ & $\begin{array}{l}\text { management of the dietary, life-style } \\
\text { and social conduct of the patient } \\
\text { including parihara kala }\end{array}$ \\
\hline $\begin{array}{l}\text { collection of necessary } \\
\text { drugs and other materials }\end{array}$ & \begin{tabular}{l} 
niskramana of the patient \\
\hline $\begin{array}{l}\text { kuti pravesha of the patient } \\
\text { preparation of the patient } \\
\text { including samshodhana }\end{array}$
\end{tabular} & $\begin{array}{l}\text { observance of nitya } \\
\text { Rasayana for the rest of the life }\end{array}$ \\
\hline
\end{tabular}

\section{Achara Rasayana, A Moral Philosophy}

Ethics means the discipline dealing with what is morally good and bad, with moral duty and obligation ${ }^{(9)}$. It is very interesting to find such moral values also imparted within the Rasayana tantra. They are called achara Rasayana. Maintaining a moral conduct of a person keeps not only himself / herself healthy, but also contributes to the sustenance of a healthy society (prasannatma). Here, the regular studying is also prescribed as Rasayana (shastrapara,... Rasayanam) ${ }^{(10)}$. It is prescribed that, one should observe this regimen regularly throughout the life (nitya, Rasayanaprayogo yasya sa nitya Rasayana.) ${ }^{(11)}$. The prescriptions given as achara Rasayana can be broadly categorized into two groups.

1) Ahara prescriptions (Dietary measures) and

2) Vihara prescriptions (Lifestyle measure)

\subsection{Ahara Prescriptions Dietary Measures}

Every life form depends upon food and it says, "you are what you eat". This essential aspect of the human beings is taken care of under dietary measures. Rasayana tantra is defined as the preserving of the proper circulation of rasa dhatu in a prime state. From the rasa dhatu, all other remaining dhatu get the required nourishment. If rasa dhatu does not have proper nutrients, which leads to the anuloma ksaya of other dhatu. For example, the brain matter is similar to the appearance of ghee (mastulunga sadrsha, ghrtam). Achara Rasayana prescribes regular 
intake of ghee and milk (nitya, ksiraghrtashinam), which ensures regular protection and nourishment for the brain by ghee. This can be explained by the samanya vishesa padartha. ${ }^{(12)}$ Not only, the medicinal value of food (Ahari mahabhaisajyam - Kashyapa), but also the importance of regular consumption of food (samashana) in a proper quantity (matrashi) ${ }^{(13)}$ have been recognized since long by the great teachers of Ayurveda. Pathya Ahara-sevana, hitatama ahara,sevana, satmya Ahara sevana in proper time bring the excellence of Ahara or dietary measures, while avoidance of apathya Ahara, Ahitatama Ahara, asatmya Ahara sevana ${ }^{(14)}$

\subsection{Vihara Prescriptions (Lifestyle Measure)}

Even though, rasa dhatu is full of nutrients, there will be no nourishment, if it does not get properly circulated. Bringing the nutrients from kostha to shakha and the metabolic waste from shakha to kostha, become possible only by the maintain of proper circulation and microcirculation. With the help of samanya vishesa padartha, the circulation can also be augmented and inhibited. For augmenting the circulation, various exercises have been recommended. Yoga proves very beneficial in this respect. Body and mind both should be in accord with the day-to-day life. Not indulging in vega-dharana ${ }^{(15)}$, also facilitates the circulation, because it causes the patency of the channels. Social as well as personal conducts of a person are good parameters, which directly reflect his/her general health, i.e., personal hygiene. Hence, having a good conduct denotes the health. As indications of both the sukha and hita Ayusa ${ }^{(16)}$, virtuous conduct of a person has been specified by the great sages. Sattvika behavior combined with egoless personality will be the ideal vihara. The Vihara prescriptions (Lifestyle measure) can also be subcategorized roughly into two groups ${ }^{(17)}$. They are

- personal conduct

- $\quad$ social conduct

The Sattvika conduct can be included under the personal conduct.

\section{Rasayana and Modern Perspectives}

Cellular nutrition and its vitality as a whole are highly conducive to the healthiness of the body. Thus, providing nutrition to the cells situated away from the place of absorption plays a significant role in the maintenance of health. Production of the optimum rasa dhatu and its absorption all depend upon the proper function of transformation (agni). Regardless of the type of tissue, cells and their organelle constantly metabolize large number of molecules. Once the supply does not meet the removal or vice versa, the resultant deficiency (ksaya) or accumulation (vrddhi), first establishes the functional pathology, which later becomes the structural pathology. Functional pathology, due to the early stage, may be mild and reversible, whereas structural one, due to chronicity, might be severe and irreversible. "Ayana" word emphasizes the proper supply as well as matched draining, jointly known as circulation. Number of models has been presented by recent scientists to understand the Rasayana therapy effects. These modalities, however, collectively rather than individually do the justification to Rasayana tantra. They are

1) Anti-oxidant effect

2) Immuno-modulatory effect

3) Anti-stress and adaptogenic effects

4) Nootropic effects

5) Anabolic effects 
6) Anti-aging effects

7) Caloric restrictions

\subsection{Antioxidant Effect}

A high oxygen consumption during an acute inflammation is termed as "respiratory burst", and NADPH oxidase is responsible for this ${ }^{(18)}$. During respiratory burst, the free radical is formed. A free radical is an electrically charged atom or group of atoms with an unpaired electron in the outermost shell. A common example is superoxide, which is formed by the addition of an electron to an oxygen molecule. Having an unpaired electron makes a free radical unstable, highly reactive, and destructive to nearby molecules. Free radicals become stable by either giving up their unpaired electron to, or taking on an electron from, another molecule. In so doing, free radicals may break apart important body molecules, ensuring organelle damage and eventual death of the cell. Several processes are responsible for the formation of free radicals in the human body. They are:

1) Normal metabolic processes

2) Intake of harmful substances, i.e., carbon tetrachloride

3) Exposing to irradiation, i.e., ultraviolet radiation in sunlight, $x$ rays

Once the production and removal of free radicals are imbalanced, that is thought to be the cause of number of disease ${ }^{(19)}$. Among the many diseases linked to oxygen-derived free radicals are cancer, atherosclerosis, Alzheimerrs disease, emphysema, diabetes mellitus, cataracts and macular degeneration, rheumatoid arthritis and general deterioration associated with aging. A good example to demonstrate this phenomenon is that, when blockage of a coronary artery (e.g., due to atherosclerosis) deprives the heart muscle of oxygen, reperfusion, the re-establishment of blood flow, may damage the tissue further. This surprising effect is due to the formation of oxygen free radicals from the reintroduced oxygen ${ }^{(20)}$.

\subsection{Immuno-Modulatory Effect}

Immune system is responsible for a number of disorders ranging from immune deficiencies to anaphylactic shock with immediate death. Even the formation of oxygen free radicals is influenced by the immune reactions. While an infection or immune reaction is taking place, it is well documented such a reaction requires a very high amount of energy. To meet such demand of energy, the blood supply is rapidly increased to that particular site by a dilated arteries (resulting hyperemia and calor). The consequent phagocytosis by neutrophils and other phagocytic cells, there is a rapid increase in oxygen consumption, resulting formation of oxygen free radicals ${ }^{(21)}$. Some Rasayana drug may influence the course of immune-reaction, by suppressing or stimulating it. If the disorder is caused by a deficiency, the stimulation plays a key role, in contrast to the suppression in a situation of hypersensitivity. If an agent can arrest the anaphylactic shock (Type I hypersensitivity) thereby preventing immediate death, such agent can be named as nectar/amrta, one term for Rasayana (in the etymology ${ }^{(22)}$. Another interesting finding is that, desensitization of patients immunologically by repeated treatment with allergens ${ }^{(23)}$ in the modern practice reflects the the concept of immune-modulation at work in that discipline also. 


\subsection{Anti-Stress and Adaptogenic Effects}

Stress has both beneficial and harmful effects on the body. The beneficial aspect of stress, known as eustress, prepares s to meet certain challenges and thus is helpful. Other stress, called distress, leads to the disease causation. Stress is caused by stressors, they are any disturbance of the human body, i.e., heat or cold, environmental poisons, toxins produced by bacteria, heavy bleeding resulted from an injury, or a strong emotional reaction. Once the stressor sets in, the body attempts to counteract it by changing the homeostatic mechanisms. If it successful, the homeostasis or health is preserved. Contrary, if the stressor is overwhelming, the normal counteracting mechanisms of the body is insufficient to relieve it, hence extreme stressors is responsible for the causation of the disease. Such changes occur in the control mechanisms of the body called the stress response or general adaptation syndrome (GAS). GAS is controlled mainly by the hypothalamus. This GAS consists of three phases, an initial fight-or-flight response, slower resistance reaction and eventual exhaustion. Although an exact relationship between stress and disease is not known, it is clear that distress can lead to particular diseases, by temporally inhibiting certain components of the immune system.

Distress-related disorders include gastritis, ulcerative colitis, irritable bowel syndrome, hypertension, asthma, rheumatoid arthritis, etc. People under prolonged distress are at a greater risk of developing chronic diseases or dying prematurely. It is scientifically proven that, interleukin-1 (IL-1) secreted by macrophages is an important link between stress and immunity (24). If any drug capable to resist the distress, such drug obviously capable to prevent the causation of chronic diseases or even the premature aging plus premature death. There by Rasayana drugs deserve the word nectar/amrta, one term for Rasayana (refer in the etymology). Furthermore, a study has revealed that, the stimulation of both cellular and harmoral immunity mediated through the activation of the psycho-neuro-endocrineimmune (PNI) axis. By this way, a single Rasayana drug is capable enough to exert numerous actions in the body ${ }^{(25)}$.

\subsection{Nootropic Effects}

It is widely accepted that, the great literary works in ancient times (no written materials available at that time) were preserved by the tradition of memorizing and oral recitation (smrti - the whole body of sacred tradition or what remembered by human teachers ${ }^{(26)}$. To keep the memory intact and to be able to remember at will, were the major problems faced by the sages. It is not surprising to understand, they hardly worked to find a solution for these burning issues, because many sages sole livelihood had been the profession of memorizing and remembering. They overcame the weakness of the human mind by inventing the control mechanisms of that weakness, such as $d h i$ (understanding), dhrti (keeping) and smrti (remember) and assorted all of them under the concept of medh" (strong intelligence) ${ }^{(27)}$. They went ahead by identifying and prescribing the food and drug articles which supposed to enhance the intellectual abilities, thus naming them as medhya Rasayana.

\subsection{Anabolic Effects}

By this theory, it hypothesizes that, Rasayana drug shows its effects of rejuvenation by its ability to build up the worn-out tissue and replenish the nutritional deficient states. An apparent weight 
gain and improved quality of life after using such drugs prove this hypothesis. Anabolism is defined as "the building up of complex chemical substances from smaller, simpler components" (28). Thus, Rasayana drugs may augment the formation of body tissue (dhatu vardhaka) by supplementing the anabolic metabolism.

\subsection{Anti-Aging Effects}

Aging is defined as "a normal process accompanied by a progressive alteration of the body $r$ homeostatic adaptive responses". It produces observable changes in structure and function and increases vulnerability to environmental disease and stress. Gerontology is the specialized discipline of medicine to study the process and problems associated with aging, while geriatrics is the specialized branch of medicine to care of the elderly. ${ }^{(29)}$

\subsection{Caloric Restrictions}

It is very interesting to find that, the caloric restrictions is instructed in every religion, for example, upavasa in Hinduism (tapopavasadhyayana), in Islam (the Holy month of Ramadan/ramazan), in Christianity (Lent, a 40 days fasting) ${ }^{(30)}$, in Jainism (upavasa), in Judaism (Yom Kippur), in Shintoism (fasting among the purification rites) and in Buddhism "vikaala bhojana", two meals per day restriction to the monks). And the practice of fasting as a therapeutic measure is well popular among the yoga practitioners as well as naturopathic practitioners. To have a such worldwide acceptability and credentials, it must have a strong scientific basis. Presently, several researchers found that fasting increases the absorption surface area of the gut by $20-30 \%$, inhibits the cell growth of tumour, and maximizes the absorption efficiency by reorienting the cell lining of the intestine ${ }^{(31)}$. All these mechanisms of caloric restriction help to achieve an optimum level of circulating rasa dhatu, thereby exerting Rasayana effect on the body. This phenomena has been proved by a very latest report from the Wisconsin National Primate Research Centre (WPRC) of University of Wisconsin ${ }^{(32)}$.

- Decrease in oxidative stress and damage

- decrease in glycation or glycoxidation hypometabolic state

- alterations in gene expression and protein degradation and

- Neuron endocrine changes.

- Thus, proved the wisdom of the great teachers of Ayurveda.

\section{Discussion}

Rasayana therapy is given due credentials by both the branch of Ayurveda, because, its innumerable capabilities. It really deserves to be called as nectar/amrta (refer to immunemodulatory and anti-stress sections). If Ayurveda as a whole, is able to conquer diseases, similarly Rasayana tantra is also capable enough to triumph over the same. With the advancement of the modern medicine, the new dimensions of Rasayana tantra will come into light. Even though, Rasayana tantra is a single branch of Ayurveda, it covers a vast range of medical activities such as, antioxidant effect, immune-modulatory effect, anti-stress and adaptogenic effects, nootropic effects, etc. Thus, it proves the claims, which assert that, the Ayurvedic compositions are codified literature. 


\section{Conclusion}

Rasayana-chikitsa is well explained in Ayurvedic samhita. That ancient knowledge rasayana chikitsa is used to prevent so many diseases in present era very well.so its review article is an attempt to describe on detail about Rasayana-chikitsa, epidemiology, types, methodology and its effect on the body.

\section{References}

[1] Tripathi B.chokhamba, "Astanga-hrudayam" Sanskrit prakashan, New Delhi,2014, sutra-stan, Chapter no.01, verse no.05, 05pp.

[2] Monier-Williams, M., "A Sanskrit-English Dictionary", Bharatiya Granth Niketan, New Delhi,2004, 869pp.

[3] Monier-Williams, M., “A Sanskrit-English Dictionary”, Bharatiya Granth Niketan, New Delhi,2004, 84pp and 163pp.

[4] Tripathi Bramhanand Charak Chandrika hindi commentary on Charak samhita of agnivesha, vol. $2^{\text {nd }}$ Chaukhambha Surbharti Prakashan, Varanasi, 2010, chikitsa-stan, Chapter 1, rasayana pada $1^{\text {st }}$ verse no.16, Page no.

[5] Tripathi Bramhanand Charak Chandrika hindi commentary on Charak samhita of agnivesha, vol. $2^{\text {nd }}$ Chaukhambha Surbharti Prakashan, Varanasi, 2010, chikitsa-stan, Chapter 1, rasayana pada $4^{\text {st }}$ verse no.07, Page no.

[6] Sharma A., Shushruta samhita edited by susrutavimarshini Hindi commentary,chawkhamba

[7] surbharti prakashana Varanasi 2004, chikitsa-stana, chapter no. 27 verse no.02pp

[8] Gupt kaviraj Atridev hindi commentary on Charak samhita of agnivesha, vol. ${ }^{\text {nd }}$ Bhargavapushtakalaya Prakashan,banaras ,2000, chikitsa-stan, Chapter 1, rasayana pada $1^{\text {st }}$ verse no.17-27, $168-169 \mathrm{pp}$

[9] Gupt kaviraj Atridev hindi commentary on Charak samhita of agnivesha, vol. ${ }^{\text {nd }}$ Bhargavapushtakalaya Prakashan,banaras, 2000, chikitsa-stan, Chapter 1, rasayana pada $1^{\text {st }}$ verse no.24, 199 $\mathrm{pp}$

[10] http://www.merriam-webstar.com/dictionary/etics

[11] Gupt kaviraj Atridev hindi commentary on Charak samhita of agnivesha, vol.2 ${ }^{\text {nd }}$ Bhargavapushtakalaya Prakashan,banaras, 2000, chikitsa-stan, Chapter 1, rasayana pada $4^{\text {th }}$ verse no.30-34 ,242 pp

[12] Gupt kaviraj Atridev hindi commentary on Charak samhita of agnivesha, vol.2 ${ }^{\text {nd }}$ Bhargavapushtakalaya Prakashan,banaras, 2000, chikitsa-stan, Chapter 1, rasayana pada $4^{\text {th }}$ verse no.35,242 pp

[13] Gupt kaviraj Atridev hindi commentary on Charak samhita of agnivesha, vol. $2^{\text {nd }}$ Bhargavapushtakalaya Prakashan,banaras, 2000, sutra-stan, Chapter 1, verse no.44,08 pp

[14] Gupt kaviraj Atridev hindi commentary on Charak samhita of agnivesha, vol. $2^{\text {nd }}$ Bhargavapushtakalaya Prakashan,banaras, 2000, sutra-stan, Chapter 05, verse no.03,63 pp

[15] Gupt kaviraj Atridev hindi commentary on Charak samhita of agnivesha, vol. $2^{\text {nd }}$ Bhargavapushtakalaya Prakashan,banaras, 2000, sutra-stan, Chapter 25, verse no.38-39, 285 pp

[16] Gupt kaviraj Atridev hindi commentary on Charak samhita of agnivesha, vol. $2^{\text {nd }}$ Bhargavapushtakalaya Prakashan,banaras, 2000, sutra-stan, Chapter 07, verse no.26,68 pp.

[17] Gupt kaviraj Atridev hindi commentary on Charak samhita of agnivesha, vol. $2^{\text {nd }}$ Bhargavapushtakalaya Prakashan,banaras, 2000, sutra-stan, Chapter 30, verse no.24,366 pp

[18] Sharma, A.K., "Elements of Ras\&yana Therapy in shyurveda", Sri Satguru Publications, 2005, 70pp. 
[19] Sembulingam, K., Sembulingam, P., "Essentials of Medical Physiology - 4 th edition", Jaypee Brothers, 2007, 90pp.

[20] Tortora, G.J., Derrichson, B., "Principles of Anatomy and Physiology - 11th edition", John Wiley and Sons, Inc., 2006, 32pp.

[21] Tortora, G.J., Derrichson, B., "Principles of Anatomy and Physiology - 11th edition", John Wiley and Sons, Inc., 2006, 708pp.

[22] Sembulingam, K., Sembulingam, P., "Essentials of Medical Physiology - 4 th edition", Jaypee Brothers, 2007, 90pp.

[23] Monier-Williams, M., "A Sanskrit-English Dictionary", Bharatiya Granth Niketan, New Delhi,2004, 869pp.

[24] Roitt, I., "Roittrs Essential Immunology - 9th edition", Blackwell Science Ltd., 1997, 335pp.

[25] Tortora, G.J., Derrichson, B., "Principles of Anatomy and Physiology - 11th edition", John Wiley and Sons, Inc., 2006, 652-654pp.

[26] Babu, S.S., Jyothi, P., "Research Methodology for Ayurvedic Scholars - 2nd edition", Chaukhambha Orientalia, 2004, 29pp

[27] Monier-Williams, M., "A Sanskrit-English Dictionary", Bharatiya Granth Niketan, New Delhi,2004, 1272pp.

[28] Monier-Williams, M., "A Sanskrit-English Dictionary", Bharatiya Granth Niketan, New Delhi,2004, 516pp. 519pp, 1272pp, 833pp

[29] Tortora, G.J., Derrichson, B., "Principles of Anatomy and Physiology - 11th edition", John Wiley and Sons, Inc., 2006, 6pp.

[30] Tortora, G.J., Derrichson, B., "Principles of Anatomy and Physiology - 11th edition", John Wiley and Sons, Inc., 2006, 98pp.

[31] http:// www.mdpi.com/2077-14444/10/2/123/htm

[32] Babu, S.S., Jyothi, P., "Research Methodology for Ayurvedic Scholars - 2nd edition", Chaukhambha Orientalia, 2004, 18pp.

[33] Weindruch, R., et al., "Aging monkeys show dramatic health benefits", Wisconsin National Primate Research Center nWPRC), University of Wisconsin-Madison, http://www.primate.wisc.edu/wprc/Centerline/03spring/, accessed March 15, 2009).

*Corresponding author.

E-mail address: shriramragad1992@gmail.com/sunil.mehetre@ rediffmail.com 